\title{
Happiness of Working Mothers Through Family Life Stages
}

\author{
Tina Afiatin, Ilma Putri Istianda, Annisa Yuliarahma Wintoro \\ Lettytia Ulfa, and Febri Meroyani Bulo \\ Faculty of Psychology Universitas Gadjah Mada
}

\begin{abstract}
The happiness of working mothers greatly affects the well-being of family. The objective of this study is to examine the happiness of working mothers in the stages of family life cycle of having: (a) the first child aged 0-35 month old; (b) the first child at pre-school age; (c) the first child at school age; (d) the first child at adolescent age; and (e) the first child who has married, by controlling the effect of work-family balance. Participants were 526 working mothers with children and a working husband. Data were collected using the Happiness Scale and the Work-Family Balance Scale. Data were analyzed using ANCOVA. The results showed that there were differences in the happiness of working mothers at different stages of family life cycles $(F=2.55 ; p<.05)$. Working mothers with the first child at preschool age had the highest level of happiness, whilst those with the married first child had the lowest level of happiness. The levels of working mothers' happiness were mostly influenced by the level of work-family balance rather than family life cycle.
\end{abstract}

Keywords: happiness, family lifespan, work-family balance

Kebahagiaan ibu bekerja sangat besar pengaruhnya terhadap kesejahteraan keluarga. Penelitian ini bertujuan untuk mengetahui tingkat kebahagiaan ibu bekerja pada tahap keluarga dengan: (a) anak pertama usia 0-35 bulan; (b) anak pertama usia pra-sekolah; (c) anak pertama usia sekolah; (d) anak pertama usia remaja; dan (e) anak pertama yang sudah menikah, dengan mengendalikan pengaruh tingkat keseimbangan kerja-keluarga. Subjek penelitian adalah 526 ibu bekerja yang memiliki anak dan suaminya juga bekerja. Pengumpulan data menggunakan Skala Kebahagiaan dan Skala Keseimbangan Kerja-Keluarga. Analisis data menggunakan ANAKOVA. Hasil penelitian menunjukkan terdapat perbedaan tingkat kebahagiaan ibu bekerja ditinjau dari tahap perkembangan keluarga $(F=2.55 ; p<.05)$. Ibu bekerja pada tahap keluarga dengan anak pertama usia pra-sekolah memiliki tingkat kebahagiaan paling tinggi, ibu bekerja pada tahap keluarga dengan anak pertama sudah menikah memiliki tingkat kebahagiaan paling rendah. Tingkat kebahagiaan ibu bekerja lebih dipengaruhi oleh tingkat keseimbangan kerja-keluarga daripada tahap perkembangan keluarga.

Kata kunci: kebahagiaan, rentang kehidupan keluarga, keseimbangan kerja-keluarga

Happiness is a key to success. Individuals who are happy tend to have a greater capacity to increase productivity and performance. Individuals who are happy also tend to have good health and a longer lifespan (Diener \& Chan, 2011). Individuals who are happy have the qualities that are expected by many people. They are more participative in the community, well-liked by others, have fewer divorces, live longer, and have a good working performance (Staw et al., cited in Diener, 2000).

According to Weiten, Dunn, and Hammer (2012),

Correspondence concerning this article should be addressed to Tina Afiatin, Faculty of Psychology, Universitas Gadjah Mada Jalan Sosio Humaniora Bulaksumur, Yogyakarta 55281. E-mail: afiatin04@ugm.ac.id; afiatin2003@yahoo.com various studies that have been conducted showed that the factors that have important influence on happiness are: (a) love, marriage, and relationship satisfaction factors; (b) work factor, and (c) genetic and personality factors. The results of research on happiness in Indonesian society showed that the most important source of happiness is family (Jaafar, Mohammed, Hanapiah, Afiatin, \& Sugandi, 2008; Afiatin, 2009; Anggoro \& Widhiarso, 2010). Various changes to, structure, function and development of the family will affect the level of happiness of the family members.

According to Rashid, Nurdin, Omar, and Ismail (2011), family and work are very important components for most people, and have a huge impact on 
their life satisfaction. Bianchi and Milkie (2013) stated that recent studies on family and work are mostly focused on working mothers. This is related to the change in demographic trends such as the increasing diversity of family and the workplace as well as an increase in labor participation of mothers. In 2000-2010 there was an increasing diversity from many families having two parents, husband as a breadwinner and wife as a homemaker, to becoming families with different types such as those with two working parents, gay or lesbian family, a family with divorced parents, families with a single parent, and families with stepparents. In addition, the workplace has also had significant changes with the increasing flexibility of place and time of work. These changes will affect the lives of working mothers and the balance between work and family. Happiness in a working mother is influenced both by factors derived from family, especially marital happiness, as well as factors associated with job satisfaction.

Findings by Arfidianingrum, Nuzulia, and Fadhallah (2013) in their study of a mother who worked as a nurse showed a negative relationship between adversity intelligence and work family conflict. This means that the higher the mother's adversity intelligence, the lower the family work conflict will be. Work-family conflict was found to be associated with lower mental health (Grzywacz \& Bass, 2003); family dysfunction (Coltrane, 2000); job and life dissatisfaction (Kossek \& Ozeki, 1998); and a decrease in family and job well-being (Kinnunen \& Mauno, 1998).

Results of previous studies showed that when people have difficulty managing work-family balance, they tend to experience negative consequences. Meanwhile, if people are able to carry out a variety of roles in the family and work successfully, these roles will enrich their life (Rashid et al., 2011).

Recently, there is an increase in families with two working parents (dual career family). Data from the Kementerian Tenaga Kerja dan Transmigrasi Republik Indonesia (2012) showed that female labor participation rate increased every year. Comparison of the working population between men and women 2008 was $62.1 \%$ versus $37.9 \%$, in 2009 became to $61.77 \%$ versus $38.23 \%$, and in 2010 was $61.42 \%$, versus $38.58 \%$. Based on data from the Badan Pusat Statistik (2013), the number of female labor force was up to $45,154,196$ or $19.33 \%$ of Indonesia's population in 2010. By 2011, that number rose to $47,139,551(19.95 \%)$ and in 2013 to $46,793,155$ (19.33\%).

The increasing number of working women can cause changes to 'de-traditionalise' the structure and dynamics of the family (Cantera, Cubells, Martinez, \& Blanch, 2009). Egalitarian relationship between husband and wife cause the social structure between the functions of masculine and feminine function to be more flexible. Double income families made husbands and wives share power and domestic responsibilities as well as career commitments. In addition to increasing earnings, families with double incomes can cause stimulation and personal fulfillment as well as strengthen the relationship between father and child as a result of the delegation of roles between of husband and wife (Tsang, Harvey, \& Sommer, 2003). Study findings by Lupri and Frideres (cited in Tsang et al., 2003) showed that families with working mothers provides important and positive effect on marital satisfaction for both the husband and the wife. This is because working mothers who earn income can experience increased self-esteem, confidence and personal independence. Furthermore, various research results showed that marital satisfaction could be a predictor of happiness, psychological well-being and quality of life (Diener, Suh, Lucas, \& Smith, 1999; Easterlin, 2003).

Cron (2001) stated that marital satisfaction is a very important factor for the well-being of working mothers. Results of previous studies showed that marital happiness showed a "U-shaped" pattern, which means that the relationship between marital happiness and marital duration tends to have a curvilinear relationship (VanLaningham, Johnson, \& Amato, 2001). Marital happiness tends to be high in early marriage and subsequently decline along with the presence of children demanding the roles and responsibilities of parents (parental years), and subsequent marital happiness tend to increase in further years (postparental years). For working mothers, family experience is related to the experience in the working environment. The ability of working mothers to adjust their role as a mother in the family and as a professional career woman will influence their subjective well-being and life satisfaction (Ruderman, Ohlott, Panzer, \& King, 2002).

According Voydanoff (2004), the relationship of roles in the family as well as at work when a person's ability in one role can enhance the other role is called work family facilitation. Individuals who emphasise the positive things on the roles that are done in the family and the workplace will achieve a family-work balance. Family-work balance contributes to the well-being of individuals, good health, and the ability to function properly in a social environment (Halpern, 2005). Individuals who are able 
to utilize the positive source of the family's role in improving the quality of work will tend to experience happiness (Jaga, Bagraim, \& Williams, 2012).

Balancing the role in the family and at work, especially as a working mother, is not easy to do. Keene and Quadagno's (2004) result showed that 60\% of adults found it difficult to have a work-life balance, especially for married partners who both work and who have children under 18 years of age. Results of the study by Handayani, Maulia, and Yulianti (2012) on working women in Indonesia showed that the performance of female lecturers was influenced by their work-family conflict. Female lecturers who experience high levels work-family conflict will have lower performance. Nyaphisi (2013) indicated that Javanese women who work as street vendors still prioritise their family over their work despite being able to effectively fulfil their roles as both as a mother and as a worker.

Research by Crossley and Langdridge (2005) showed that in women, the key to happiness is being able to help others, having a close family, and being loved by a loved one. This is in line with her developmental goal as a middle aged woman which is generativity, with duties related to reproduction, nurturing, and guiding the next generation (Lachman, 2004). The working mothers' dynamics of happiness is also influenced by the family's stage of development.

Duvall (cited in DeGenova \& Rice, 2005; Goldenberg \& Goldenberg, 2008) mentioned that the developmental stages of the family in eight stages are based on time duration. Each stage has implications in needs relating to household, health care, entertainment, education, house management, tasks and family sources. The eight stages of family life include: (1) Married couple (not having children); (2) Productive family (birth of first child, the eldest aged 0-30 months); (3) Families with pre-school age children (the eldest child aged 30 months- 6 years); (4) Families with school children (oldest child ages 6-13 years); (5) Families with teenaged children (the eldest aged 13-20 years); (6) The family as a launching pad (the first child to the last child left home to raise a family); (7) Parents of middle-aged ("empty cage" until retirement); and (8) Aging family members (retirement until the death of both spouses). Changes at each stage of development created transitional conditions that need to be achieved. These stages of development of the family and the main transition to be achieved are presented in Table 1 .

Based on Table 1, it can be seen that each stage of development requires different development tasks and family changes. Weiten, Dunn, and Hammer (2012) stated that although many parents feel happy with their decision to have a child, the birth of a child creates an important transition that disrupts routines and creates emotional difficulties. The transition to become a parent tends to have more impact on mothers than fathers. New mothers often feel tired with the childbirth process, and some of them even experience post-natal depression.

Research by Dennis and Ross (2005) showed that $10-13 \%$ of new mothers experience post-natal de-

\section{Table 1}

Common Transition Points Through the Life Cycle

Stage of Development (Duvall Stage)

1. Married couple

2. Childbearing family

3. Preschool children

4. School children

5. Teenagers

6. Launching children

7. Middle-aged parents

8. Aging family members
Major Transition to be Achieved

Commitment to each other

Developing parent roles

Accepting child's personality

Introducing children to institutions (school, social group, religious groups)

Accepting adolescence (social and sexual role changes)

Experimenting with independence

Accepting child's independent adult role

Letting go-facing each other again

Accepting old age

Note. Source: Goldenberg, H., \& Goldenberg, I. (2008). Family Therapy. An Overview. p. 33 (Based on Duvall, 1977, and Barnhill and Longo, 1978) 
pression 12 weeks after childbirth. Risk factors include a history of depression, high levels of stress, and marital dissatisfaction (O'Hara, 2009).

According to Higgins, Duxbury, and Lee (1994) stages of family development need to be considered as variations in the role demands of work and family. Results of previous studies showed that workfamily conflict increases with the demands of marriage and the presence of children. Furthermore, it is stated that the conflict will decrease with the increasing age of the youngest child. This is related to the level of responsibility of parents. Parents with children under six years experienced the highest level of conflicts, followed by parents with schoolage children (ages 6-18 years). This can be explained by a job-strain model that stress would be the highest in situations where individuals have little or no control over stressful environment. Parents (especially mothers) of dependant children experience more family demands than those with older children. These higher demands, such as managing childcare, taking children to and from school, and caring for a sick child, result in lower levels of control to cope with the demands of work and family. Consequently, work-family conflict is high. When the children get older, however, the demand that is mainly related to parenting will be reduced, thus increasing the level of control and reduce stress to parents.

Working mothers experience more conflicts than men due to their different role in the family (Harsiwi, 2004). This difference was due to the fact that men' has a more flexible responsibility around the house, while women's work are done mostly as a routine, such as responsibility to the children, especially those under 18 years of age (Ahmad, 2005; Ford, Heinen, \& Langkamer, 2007).

The change of phase of marriage by the presence of children requires the ability for couples to become the nurturers of the younger generation while simultaneously continue to build marital relationship (Markey, 2005). Parents work together in parenting, finances and household chores and make new adjustments with extended family while trying to balance their career with child care. These double adjustments often cause issues and commonly causes decreased marital satisfaction. Husbands and wives need a lot of time and energy to nurture and care for their children and change the whole quality of the marriage. In the phase of marriage with teenage children, a change to the role of parents occurs. The relationship of children and parents changed signifycantly. Parents often see the teenager as being in a dif- ficult and challenging stage. The heavy burden of raising teenagers causes the lowest levels of marital satisfaction in the mid-marriage (Papalia, Stern, Feldman, \& Camp, 2007). Furthermore, according the study by Proulx, Helms, and Cheryl (2007) on individuals who are married, marital satisfaction is strongly predictive of personal well-being.

On a launching family stage, transition occurs as children become more independent. Aquilino (1997) stated that when family lets go of children to be married, conflict reduces and parent-child relationship becomes closer and supportive.

Based on the earlier explanations, it can be stated that the happiness of working mothers is influenced by the family's stage of development and work-life balance. Different development stages will vary the levels of dependence of children to their mother and consequently the burden of the mothers. On a stage with the first born aging less than three years old, the child's dependency will be really high, making the burden to mothers even heavier. This will negatively influence the happiness of mothers. Along with the growth of a child, dependency will reduce and happiness of mothers will increase.

Working mothers who are at the stage of launching family development family will have less burden and conflict due to the increasing independence of children, and the relationship between mother and child will become closer and mutually supportive. Consequently, this will lead to a higher level of happiness. Individuals who are able to utilize the positive source of the family's role in improving the quality of their work will tend to feel happy. Thus, working mothers who are able to match her role as the mother in the family with the level of workfamily balance will be happy. The hypothesis of this study is that there will be a difference between the level of happiness of working mothers among mothers who have a family with firstborn child aged of 0-35 months, the first child aged 3-6 years; the first child aged 7-12 years, the first child aged 13-21 years, and a married first child, while controlling the level of work-family balance.

\section{Method}

This study used a comparative method. The variables included in the study are: family development stage, work-family balance, and happiness of working mothers. The measurements used are the Happiness Scale for working mothers and the Work-Family 
Table 2

Measurements Used in the Study

\begin{tabular}{|c|c|c|c|c|}
\hline No & Scale Name & $N$ & $\begin{array}{c}\text { Number of Items and Total Correlation } \\
\text { Coefficient }\end{array}$ & Reliability Coefficient \\
\hline 1. & $\begin{array}{l}\text { Happiness of Working } \\
\text { Mothers }\end{array}$ & 97 & $35(.417-.659)$ & .946 \\
\hline 2. & Work-Family Balance & 97 & $29(.336-.810)$ & .943 \\
\hline
\end{tabular}

Table 3

Subject Demographics

\begin{tabular}{|c|c|c|}
\hline $\mathrm{No}$ & Demographic Factor & $\overline{\text { Percentage }}$ \\
\hline \multirow[t]{4}{*}{1.} & Job category & \\
\hline & Government & $47.1 \%$ \\
\hline & Private & $39.5 \%$ \\
\hline & Enterpreneur & $13.3 \%$ \\
\hline \multirow[t]{3}{*}{2.} & Age & \\
\hline & Early adult (20-40 years) & $62.7 \%$ \\
\hline & Middle adult (40-60 years) & $37.3 \%$ \\
\hline \multirow[t]{6}{*}{3.} & Stage of development & \\
\hline & Less than three years old & $23.2 \%$ \\
\hline & Pre-school & $19.2 \%$ \\
\hline & Elementary & $20 \%$ \\
\hline & Young adult & $22.2 \%$ \\
\hline & Married & $15.4 \%$ \\
\hline \multirow[t]{7}{*}{4.} & Education & \\
\hline & Elementary & $1.4 \%$ \\
\hline & Junior High School & $4.3 \%$ \\
\hline & High School & $20.7 \%$ \\
\hline & Diploma & $26.4 \%$ \\
\hline & Bachelor & $40.7 \%$ \\
\hline & Postgraduate & $6.6 \%$ \\
\hline \multirow[t]{7}{*}{5.} & Income & \\
\hline & $<$ IDR $1,000,000.00$ & $17.3 \%$ \\
\hline & IDR $1,000,000.00-$ & $35.3 \%$ \\
\hline & IDR 2,500,000.00 & \\
\hline & IDR 2,500,000.00 - & $41 \%$ \\
\hline & IDR 5,000,000.00 & \\
\hline & $>$ IDR 5,000,000.00 & $6.4 \%$ \\
\hline
\end{tabular}

Balance scale. The Happiness Scale consisted of two subscales which are the Positive Affect Negative Affect Scale (PANAS) and Satisfaction with Life Scale (SWSL). The scale includes 61 items and has been modified from the Happiness Scale used by Kuswardani (2010). PANAS used a likert model to describe the frequency of a situation. Each item consists of five answer options which include HTP (almost never), J (rarely), KK (sometimes), SS (often), and HSL (almost always). Score for each item ranges from one to five. For 'favorable' items, a score of five is given for HSL and a score of one for HTP. For 'unfavorable' items, a score of one is given for HTP and a score of five for HSL.
SWLS (Satisfaction with Life Scale) used a modified Likert scale to indicate the degree of conformity with the statement. Each item has four answers options, which are SS (very appropriate), S (as appropriate), TS (not appropriate), and STS (very inappropriate). Scores for each item ranged from one to four. For 'favorable' items, a score of four is given for SS and a score of one for STS. For 'unfavorable' items, a score of one is given for SS and a score of four for STS. Happiness score is the sum score of the Positive Affect (PA) deducted with a score Negative Affect (NA) and added with a score of Satisfaction With Life Scale (SWLS). Two subscales, namely Positive Affect Negative Affect Scale (PANAS) and Satisfaction With Life Scale (SWLS) has different number of items and responses, so the amount of raw scores for each subscale on each subject needs to be standardized in advance. Raw scores on each happiness subscale are first converted into a $\mathrm{z}$ score and subsequently converted into the $T$ score. Higher scores on the happiness subscale indicate higher levels of happiness and vice versa.

The Work-Family Balance scale was used to reveal subjects' level of work-family balance. This scale is constructed based on three aspects explained by Greenhaus, Collins, and Shaw (2003) which are balance of time, balance of involvement, and balance of satisfaction. This scale consisted of 29 items, using a likert scale to indicate subjects' agreement towards statements. Each item had five options which are SS (strongly agree), S (agree), N (neutral), TS (disagree), and STS (strongly disagree). Each item's score ranged from one to five. For 'favorable' items, a score of five is given for SS and a score of one for STS. For 'unfavorable' items, a score of one is given for SS and a score of five for STS. Higher scores on this scale indicates better worklife balance, and vice versa.

Both scales (Happiness Scale and Work-Family Balance Scale) have been tested previously on 97 working mothers. Based on the test, the quality of the scale is provided in Table 2. 
Participants in this study are working mothers who are married and who have children. Subjects amounted to 526 people. The study was conducted in Yogyakarta City, Sleman and Bantul Regency. Data collection was done between May 28th 2014 to July 10th 2014. Subjects were mothers who work in formal and informal sectors. The authors collected data through formal permission from Yogyakarta Administration Bureau and Yogyakarta Licensing Department. After obtaining permission, data were collected in government offices, banks, hospitals, schools, and residential areas. The study used a nonrandom sampling, by giving the scales to subjects in places that have been permitted. Data collection was done in Yogyakarta, Sleman, and Bantul through a door-to-door method. Subject demographics can be seen in Table 3.

\section{Results}

Data was analyzed using covariance technique with Stastical Product and Service Solution (SPSS) 16.0 for Windows Release. The author categorized the score of each subject on the happiness of working mothers and work-family balance into low, medium, and high categories. Results of the categorization for work-family balance variable are presented in Table 4.

Results of the categorization for happiness of working mothers variable is presented in Table 5.

\section{Assumption Testing}

Assumption testing was done prior to data analysis to check whether the data is appropriate to be analysed using analysis of covariance (ANCOVA).
The results for the assumption testing are as follows: (1) Normality testing. Normality test results on happiness variable using One-Sample Kolmogorov-Smirnov Test yielded K-S-Z value of 1.332 ( $p$ $>$.05) so it can be concluded that the data was distributed normally; (2) Linearity testing. Linearity test result on happiness variable with work-family balance variable showed an $F$ linierity score of 143.123 $(p<.05)$, thus both variables have a linear relationship; (3) Homogeneity testing. Homogeneity test used was Levene's Test, and a score of $F=1.72$ ( $p$ $>.05)$ was obtained. This means that the variances among different family development stages are equal. Results from assumption tests indicated that the data fulfilled the criteria for an ANCOVA analysis.

\section{Hypothesis Testing}

The hypothesis of this study was: "There will be a difference between the level of happiness of working mothers among mothers who have a family with firstborn child aged of 0-35 months, the first child aged 3-6 years; the first child aged 7-12 years, the first child aged 13-21 years, and a married first child by controlling the level of work-life balance"

ANCOVA results yielded a score of $F=2.549$ ( $p$ $<.05$ ), indicating a significant difference of happiness levels among working mothers with a first child aged 0-35 months, first child aged 3-6 years, first child aged 7-12 years, first child in teenage years, and first child who is married (controlling for worklife balance). Effective contribution of family stage development on mother's happiness is $1.9 \%$. Worklife balance variable was shown to influence happiness of working mothers variable. Effective contribution of work-life balance on happiness of working mothers is $22.8 \%$.

Table 4

Categorization of Subjects of the Work-Family Balance Variable

\begin{tabular}{lcccr}
\hline Category & Norm & Score & Number & Percentage \\
\hline Low & $\mathrm{X}<(\mu-1 \sigma)$ & $\mathrm{X}<94,05$ & 90 & $17.1 \%$ \\
Medium & $(\mu-1 \sigma) \leq X<(\mu+1 \sigma)$ & $94.05 \leq X<121.31$ & 370 & $70.3 \%$ \\
High & $\mathrm{X} \geq(\mu+1 \sigma)$ & $\mathrm{X} \geq 121.31$ & 66 & $12.5 \%$ \\
\hline Note & & &
\end{tabular}

Table 5

Categorization of Subjects of the Happiness of Working Mothers Variable

\begin{tabular}{lcccr}
\hline Category & Norm & Score & Number & Percentage \\
\hline Low & $X<(\mu-1 \sigma)$ & $X<26,60$ & 74 & $14.1 \%$ \\
Medium & $(\mu-1 \sigma) \leq X<(\mu+1 \sigma)$ & $26.60 \leq X<73.40$ & 384 & $73 \%$ \\
High & $X \geq(\mu+1 \sigma)$ & $X \geq 73.40$ & 68 & $12.9 \%$ \\
\hline
\end{tabular}

Note. Mean: 50.00; SD: 23.40. 
Mean scores of happiness levels on each stage of family development are as follows: (a) Happiness of working mother with the first child aged 0-35 months (Mean $=53.288 ; S D=1.880)$; (b) Happiness of working mother with the first child aged 3-6 years (Mean $=53.309 ; S D=2.070)$; (c) Happiness of working mother with the first child aged 7-12 years (Mean $=48.704 ; S D=2.015)$; (d) Happiness of working mother with the first child being a teenager (Mean = 47.677; SD = 1.926); and (e) Happiness of working mother with the first child being married $($ Mean $=45.958 ; S D=2.302)$.

From the post hoc test, family development stages that were found to have a significant difference on happiness levels are: a) The 0-35 months child group with teenager group $(t=5.611 ; p=.039)$; b) The 0 35 months child group with married child $(t=7.330$; $p=.014)$; c) The 3-6 year old child (preschool) group with teenager $(t=5.632 ; \mathrm{p}=.049)$; $) 3-6$ year old child (preschool) group with married child $(t=7.351 ; p=.19)$.

Based on data analyses results, it can be concluded that the average levels of mother's happiness from the lowest to the highest were: family stage development with a first child in pre-school age (36 years), less than three years (0-35 months), school aged (7-12 years), teenagers, and married child.

\section{Discussion}

The results of this study indicated that there were differences in happiness levels between working mothers and different family stages with a child aged 0-35 months, a child aged 3-6 years, a child aged 7-12 years, a child aged 13-21 years, and a child who was already married, by controlling the levels of work-family balance of working mothers. The level of happiness of working mothers, regardless of the level of work-family balance, was influenced by the stage of development of the family. Working mothers on the stage of development with pre-school aged first child (ages 3-6 years) had the highest level of happiness, while those at the stage of development with married child had the lowest level of happiness. The findings of this study is in accordance with DeGenova and Rice (2005) who stated that the family life cycle consisting of various stages of development are constantly experiencing changes in family structure and function. At each stage of development there are challenges, tasks, and problems that must be faced by working mothers.
Happiness of working mothers is a holistic evaluation of working mothers on their life quality that includes a cognitive evaluation on their life satisfaction and affective evaluation of their mood and emotion. A majority of subjects in this study $(73 \%)$ had a medium level category of happiness, and $12.9 \%$ was categorized as having a high level of happiness. This showed that individuals in the study felt satisfied with their lives and tend to experience more positive emotions rather than negative ones. Diener and Seligman (2002) stated that happy individuals will have a rich and satisfying social relationship, and will spend little time alone compared to those who are not happy.

Results of the current study showed that working mothers with pre-school aged children had a higher level of happiness compared to working mothers in other stages of family development. This may be due to their child's (3-6 years old) situation who tend to be enrolled in pre-school programs such as kindergarten. Such programs enable the child to receive facilitation especially for his/her gross motor skills such as jumping, climbing, or running. According to Santrock (2007), these abilities are aimed purely for entertainment purposes and children usually feel proud when they can show their abilities to their parents. Pre-school aged children also experience development in speech, increased sensitivity towards the needs of others in conversation, and learn to adapt their conversation style to fit the situation. The interaction of working mothers with pre-school children using fun activities will trigger positive affect.

Working mothers had the lowest level of happiness on a life stage where their first child is married. This according to Furstenberg (2011) could have occurred due to the fact that it is not easy to let a child go into the world of adulthood. Many challenges and problems are unable to be solved by a married child, so they often come back to the parents. A study by Aquilino (2009) showed that approximately $40 \%$ of married children live with their parents again for some time, particularly on their first few years of marriage. It is not rare for married couples to be separated, divorced, lose jobs, and therefore live back with their parents. The findings of this study is corroborated by VanLaningham, Johnson, and Amato (2001) who stated that marital satisfaction tend to have a negative correlation with marriage duration, meaning that longer marriage duration will lead to lower happiness.

The present study found that $73 \%$ of working mothers had medium levels of happiness, while $12.9 \%$ 
had high levels of happiness. This means that a majority of working mothers had medium levels of life satisfaction and positive affect. This finding is contrary to previous research that found that $90 \%$ of adults in Indonesia and Malaysia had high levels of happiness (Jaafar et al., 2008). This could be due to the use of different measurements. Jaafar et al. (2008) utilized The Oxford Happiness Questionnaire, while this study used the Positive and Negative Affect Scale (PANAS) and the SWLS.

The findings of the current study also did not support the findings by Umer and Rehman (2013) who found the low levels of happiness of mothers in Pakistan. Umer and Rehman (2013) showed that the low levels of happiness and satisfaction was due to the high levels of conflict between work and life in Pakistani culture, where the main duty of women is to do household duties such as childcare and serving her husband. This condition is in contrast to living conditions in Indonesia, especially in Java that currently provides women with the opportunity to work and not experience work-family conflict due to distribution of responsibilities with the husband (Nyaphisi, 2013).

This study also showed the effective contribution on family life stages to working mothers' happiness was $1.9 \%$, while the effective contribution of worklife balance was $22.8 \%$. This means that the happiness of working mothers is more likely to be influenced by work-family balance rather than family life stages. In other words, regardless of her family's stage of development, working mothers will have a good level of happiness if she has a good workfamily balance. Work-family balance is a condition where working mothers are able to effectively allocate time, attention, and energy to make herself satisfied with her responsibilities both at home and at work (Handayani, Afiatin, Adiyanti, \& Himam, 2015). Work-life balance has an important contribution to well-being, health, and social functioning of individuals in the society, as well as in family functionality, family satisfaction, and family wellbeing. Handayani et al. (2015) also showed the six factors influencing work-family balance of working mothers in Indonesia, which include commitment, individual character, understanding of a woman's role, social support, existence of a child, and work autonomy.

The contribution of family stage variable and work-family balance on happiness is $24.7 \%$. This means that the $25.3 \%$ of other variables' contribution need to be examined, related to the happiness of working mothers. Weiten et al. (2012) stated that other variables that have important influences on happiness are love, marriage, relationship satisfaction, and personality. Future research on the effects of family life stage on working mothers should therefore consider the level of marital satisfaction as well as the personality of working mothers.

\section{Limitation}

This survey was done in the Special Region of Yogyakarta. Samples in the study were not randomly collected, but through purposive sampling. This is considered a limitation due to the fact that the results may only be applicable to the subjects in this study, not for the population of working mothers in Yogyakarta. Thus, it suggested that future studies be done using a random sampling data collection technique.

\section{Conclusion}

The happiness of working mothers (controlling the effects of work-family balance) differ among working mothers who have a first child aged 0-35 months, a pre-school aged child, a school aged child, a teenage child, and a married child. Working mothers who have a pre-school aged first child had the highest level of happiness, while those with a married first child had the lowest level of happiness.

Happiness of working mothers was affected $1.9 \%$ by family life stage and $22.8 \%$ by work-family balance. The effect of work-family balance on happiness is more significant than family life stage. In other words, working mothers in different stages of family development could still be happy when they are able to appropriately allocate time, attention, and energy for both their work and family.

\section{References}

Afiatin, T. (2009). Subjective well-being of Aceh adolescents after Tsunami: The meaning of disaster and adolescent happiness. Anima Indonesian Psychological Journal, 25(1), 11-29.

Ahmad, A. (2005). Work family conflict among dual earner couples: comparisons by gender and profession. Jurnal Psikologi Malaysia, 19, 1-12.

Anggoro, W. J., \& Widhiarso, W. (2010). Konstruksi dan identifikasi properti psikometris instrumen pengukuran kebahagiaan berbasis pendekatan indi- 
genious psychology: Studi multitrait-multimethod. Jurnal Psikologi, 37(2), 176-188.

Aquilino, W. S. (1997). From adolescent to young adult: A prospective study of parent-child relation during the transition to adulthood. Journal of Marriage and the Family, 59, 670-686.

Aquilino, W. S. (2009). Empty nest, effects on marriage. In H. T. Reis \& S. Sprecher (Eds.), Encyclopedia of human relationships (Vol. 2, pp. 523-525). Los Angeles: Sage References Publication.

Arfidianingrum, D., Nuzulia, S., \& Fadhallah, R. A. (2013). Hubungan antara adversity intelligence dengan work family conflict pada ibu yang bekerja sebagai perawat. Retrieved from http:// journal.unnes.ac.id/sju/index.php/dep.

Badan Pusat Statistik. (2013). Perkembangan beberapa indikator utama sosial ekonomi Indonesia. Katalog BPS: 3101015.

Bianchi, S. M, \& Milkie, M. A. (2013). Work and family research in the first decade of the $21 \mathrm{st}$ century. Journal of Marriage and Family, 72, 705725. DOI: 10.1111/j.1741-3737. 2010.00726.

Cantera, L. M., Cubells, M. E., Martinez, L. M., \& Blanch, J. M. (2009). Work, family, and gender elements for a theory of work-family balance. The Spanish Journal of Psychology, 12(2), 641-647.

Coltrane, S. (2000). Research on household labor: Modelling and measuring the embeddedness of routine family work. Journal of Marriage and the Family, 62, 1208-1233.

Cron, E. A. (2001). Job satisfaction in dual-career women at three family life cycle stages. Journal of Career Development, 28(1), 17-28.

Crossley, A., \& Langdridge, D. (2005). Perceived source of happiness. A network analysis. Journal of Happiness Studies, 6, 107-135.

DeGenova, M. K., \& Rice, F. P. (2005). Intimate relationship, marriages, and families (6th ed.). New York: McGraw-Hill.

Dennis, C. L., \& Ross, L. (2005). Relationship among infant sleep patterns, maternal fatigue, and development of depressive symptomatology. Birth, 125, 276-302.

Diener, E., Suh, E. M., Lucas, R. E., \& Smith, H. L. (1999). Subjective well-being: Three decades of progress. Psychological Bulletin, 125, 276-302.

Diener, E. (2000). Subjective well-being: the science of happiness and a proposal for a national index. American Psychologist, 55, 34-43.

Diener, E., \& Seligman, M. E. P. (2002). Research report: Very happy people. Psychological Science,
13(1), 81-84.

Diener, E., \& Chan, M. Y. (2011). Happy people live longer: Subjective well-being contributes to health and longevity. Applied Psychology: Health and Well-Being, 3(1), 1-43.

Easterlin, R. A. (2003). Explaining happiness. Proceedings of the National Academy of Science, 100 (19), 176-183.

Ford, M. T., Heinen, B. A., \& Langkamer, K. L. (2007). Work and family satisfaction and conflict: A metaanalisis of cross-domain relation. Journal of Applied Psychology, 92(1), 57-80.

Furstenberg, F. F., Jr. (2001). The sociology of adolescence and youth in the 1990s: A critical commentary. In R. M. Milardo (Ed.), Understanding families into the new millennium: A decade in review. Minneapolis, M. N.: National Council on Family Relation.

Goldenberg, I., \& Goldenberg, H. (2008). Family therapy: An overview (7th ed.). Belmont, CA: Thomson Higher Education.

Grzywacz, J. G., \& Bass, B. L. (2003). Work, family, and mental health: Testing different methods of work-family fit. Journal of Marriage and the Family, 65(1), 248-262.

Handayani, A., Afiatin, T., Adiyanti, M. G., \& Himam, F. (2015). Factors impacting work family balance of working mothers. Anima Indonesian Psychological Journal, 30(4), 178-190.

Handayani, A., Maulia, D., \& Yulianti, P. D. (2012). Kinerja dosen berdasarkan konflik kerja keluarga dan motivasi berprestasi. Dalam S. Widodo, N. Hidayat, \& A. U. Sujoto (Eds.), Prosiding Seminar Hasil-hasil Penelitian (pp. 111-116). Lembaga Penelitian dan Pengabdian kepada Masyarakat IKIP PGRI Semarang.

Halpern, D. F. (2005). Psychology at the intersection of work and family: recommendation for employer, working families, and policymakers. American psychologist, 60, 397-409.

Harsiwi, A. M. (2004). Konflik kerja-keluarga dan kepuasan kerja akademisi wanita. Ekobis, 3(1), 217-229.

Higgins, C., Duxbury, L., \& Lee, C. (1994). Impact of life-cycle stage and gender on the ability to balance work and family responsibilities. Family Relations, 43, 144-150.

Jaafar, J. L. S., Muhamad, H., Hanapiah, S. A., Afiatin, T., \& Sugandi, Y. S. (2008). The index of happiness of the Malaysian and Indonesian people. Asia in Transformation: Exploring New Values in Asia, Proceeding, 1, 1-15. 
Jaga, A., Bagraim, J., \& Williams, Z. (2012). Work family enrichment and psychological health. Journal of Industrial Psychology/SA Tydskrif vir Bedryfsielkunde, 39(2), 1-10.

Keene, J. R., \& Quadagno, J. (2004). Predictors of perceived work-family balance: Gender differrence or gender simililarity. Sociological Perspective, 47, 1-23.

Kementerian Tenaga Kerja dan Transmigrasi Republik Indonesia. (2012). Rencana Pembangunan Jangka Panjang 2010-2025 Bidang Ketenagakerjaan dan Ketransmigrasian. Jakarta: Kementerian Tenaga Kerja dan Transmigrasi Republik Indonesia.

Kinnunen, U., \& Mauno, S. (1998). Antecedents and outcome of work-family conflict among employed women and men in Finland. Human Relation, 51(2), 157-177.

Kossek, E., \& Ozeki, C. (1998). Work-family conflict, policies, and the job-life satisfaction and wellbeing: A review and direction for organization behavior-human resource. Journal of Applied Psychology, 83(2), 139-150.

Kuswardani, I. (2010). Kesejahteraan subjektif pada mahasiswa ditinjau dari kematangan beragama dan efikasi diri (unpublished thesis). Faculty of Psychology, Universitas Gadjah Mada.

Lachman, M. E. (2004). Development in midlife. Annual Review of Psychology, 55, 305-331.

Markey, B. (2005). The lifecycle stages of a marriage: A Colloqium of Social Scientist and Theologist. Promoting and Sustaining Marriage as a Community of Life and Love. October, 24-25. Creighton University. Omaha, NE.

Nyaphisi, M. B. (2013). Managing work family balance among Javanese woman street-vendor: Planning and structuring daily activities, social support and quality time for family (unpublished thesis). Faculty of Psychology, Universitas Gadjah Mada.

O'Hara, M. W. (2009). Postpartum depression: What we know. Journal of Clinical Psychology, 65, 1258-
1269.

Papalia, D. E., Stern, H. L., Feldman, R. D., \& Camp, C. J. (2007). Adult development and aging. New York: McGraw-Hill.

Proulx, C. M., Helms, H. M., \& Cheryl, B. (2007). Marital quality and personal well-being: A metaanalysis. Journal of Marriage and Family, 69, 576- 593.

Rashid, W. E. W., Nurdin, M. S., Omar, A., \& Ismail, I. (2011). Self-esteem, work-family enrichment and life satisfaction among married nurses in health care service. International Journal of Trade, Economic and Finance, 2(5), 424-429.

Ruderman, M. N., Ohlott, J. P., Panser, K., \& King, S. N. (2002). Benefits of multiple roles for managerial women. The Academy of Management Journal, 45(2), 369-386.

Santrock, J. W. (2007). Children (9th ed.). New York: McGraw Hill.

Tsang, L. L. W., Harvey, C. D., \& Sommer, R. (2003). The effects of children, dual earner status, sex role traditionalism, and marital structure on marital happiness over time. Journal of $\mathrm{Fa}$ mily and Economic Issues, 24(1), 5-26.

Umer, R., \& Rehman, M. Z. (2013). Impact of work life balance and work life conflict on the life satisfaction of working women: A case study of higher education sector of twin cities of Pakistan. Academic Research International, Part-II: Social Science and Humanities, 4(5), 445-458.

VanLaningham, J., Johnson, D., \& Amato, P. (2001). Marital happiness, marital duration, and the Ushaped curve: Evidence from a five-wave panel study. Social Forces, 78(4), 1313-1341.

Voydanoff, P. (2004). The effects of work demands and resources on work to family conflict and facilitation. Journal of Marriage and the Family, 66, 398-412.

Weiten, W., Dunn, D. S., \& Hammer, E. Y. (2012). Psychology applied to modern life: Adjustment in the 21 st century. Belmont, CA: Wadsworth. 